\title{
Influence of physical protectors with different filters on the initial development of Peltophorum dubium (Spreng.) Taub seedlings
}

\author{
Jeferson Klein $^{1 *}$, João Domingos Rodrigues ${ }^{2}$, Vandeir Francisco Guimarães ${ }^{3}$, \\ Leandro Rampim ${ }^{3}$, Débora Kestring ${ }^{3}$, Daniel Schwantes ${ }^{3}$, Rubens Fey ${ }^{4}$, Valdemir Aleixo ${ }^{1}$, \\ Alfredo Richart ${ }^{1}$, Michelli Carline Ferronato ${ }^{1}$ and Augustinho Borsoi ${ }^{3}$ \\ ${ }^{1}$ Pontifical Catholic University, PUC, City of Toledo, Parana state, Brazil. \\ ${ }^{2}$ São Paulo State University, UNESP, Biological Sciences, City of Botucatu, São Paulo State, Brazil. \\ ${ }^{3}$ State University of West Parana, Unioeste, CCA/PPGA, Pernambuco Street No. 1777, P.O. Box 9, Zip Code 85960- \\ 000, city of Marechal Candido Rondon, Parana State, Brazil. \\ ${ }^{4}$ Federal University of South Border - UFFS, city of Laranjeiras do Sul, Parana State, Brazil.
}

Received 8 November, 2012; Accepted 9 September, 2014

\begin{abstract}
The use of physical protectors has been considered as an efficient technique for tillage farming of different species, mainly native ones. Based on the importance of the species, Peltophorum dubium for revegetation of degraded areas, this study evaluated the emergence, survival and initial development of $P$. dubium seedlings under the influence of physical protectors with different filters. Thus, the following treatments were adopted: absence of physical protector (APP), transparent physical protector (TPP), transparent physical protector + blue cellophane (BPP) and transparent physical protector + red cellophane (RPP). The evaluated characteristics were: emergence velocity index (EVI), seedling survival and emergence percentage, plant height, leaf area and root collar diameter. All of these physical protectors increased the mean values of EVI and survival. In conclusion, the emergence speed and initial development of $\boldsymbol{P}$. dubium (Spreng.) seedlings grown in the interior of physical protectors, independent on the filters, presented positive results. The reduction on the light intensity interferes positively in the initial growth of these plants.
\end{abstract}

Key words: Native species, reforestation, seedlings.

\section{INTRODUCTION}

Since the beginning of the millennium, the reduction of forest resources and the increase of the consumption of wood products were widely discussed because of the increasing need of reforested areas, mainly because, few existent native areas are restricted to preservation, parks and reserves (Mattei et al., 2001). The production of native seedlings species with quality and good characteristics are important for the success of $P$. dubium

${ }^{\star}$ Corresponding author. E-mail: jefersonklein@yahoo.com.br.

Author(s) agree that this artic le remain permanently open access under the terms of the $\underline{C r e a t i v e ~ C o m m o n s ~ A t t r i b u t i o n ~}$

License 4.0 Intemational Lic ense 
seedlings populations. This production must be performed using appropriate techniques which may provide an efficient and secure quality control (Souza et al., 2005), ensuring a production in quality and quantity (Neves et al., 2005) being that the seedlings are resistant to the adverse conditions. Thus, the direct seedling is a versatile technique in the reforestation process (Barnett and Baker, 1991). According to Ferreira et al. (2007), native seedlings species consist of the dispersion of seeds of the forest species being the seeds sown directly in the reforestation area. This technique have the advantage of reducing the implantation cost for forest stands, in order to eliminate the nursery stage and labor costs, while increasing its importance in areas that lack these resources or with difficult access (Soares and Rodrigues, 2008).

Derr and Mann (1971), studies with direct seedlings observed that only one technique is not enough for the protection of seedlings against adverse conditions. In this way, the use of physical protectors allowed with direct seedling become relevant, once it can cause the reduction seeds and seedlings predation. Besides, the advantage of its interference in germination and establishment of species created a favorable microenvironment (Ferreira, 2002; Mattei and Rosenthal, 2002).

In this way, the $P$. dubium (Spreng.) Taub. popularly known in Brazil as "canafistula" or "faveiro" is a native species found in all domain of the semi-deciduous forest, as well as in the Brazilian cerrado, being that these species are also profuse in secondary formations (Donadio and Demattê, 2000). These species are classified as an opportunist pioneer, tolerant to high taxes of light and temperature, and also considered as a great potential for the use of mix crops destined to the recomposition of degraded areas and areas of permanent protection (Lorenzi, 2000).

Overall, these species is prejudiced, because the production of seedlings have restrictions on the germination and initial development, which are related to tegumentary characteristics and seeds dormancy overcome with the use of physical and chemical scarifying (Salerno et al., 1996; Mattei, 1999; Perez et al., 2001; Teles et al., 2000; Oliveira et al., 2003; Paulino et al., 2004; Viecelli et al., 2011), decreasing the efficiency of seedlings obtaining.

However, other studies which quantify the increment in the initial development of native forest species in function of the light quality provided in the sowing point at the reforestation area. A pilot study conducted at a laboratory show that species as $P$. dubium present potential of susceptibility to light quality variation (Klein et al., 2012). Nonetheless, the real behavior or $P$. dubium in reforestation areas with physical protectors at field level was never evaluated. This procedure is crucial, mainly during the critical period for the establishment of one seedling comprehend in the first 30 days (Meneghello and Mattei, 2004). It is during this period of time, the protection of the seeds is essential, mainly because they can be exposed to dryness, soil compaction caused by strong rainfalls, vulnerability to be attack by birds and ants and also by the breaking in the loading and transportation of the seedlings. In this way, the use of physical protectors in the sowing of forest species is important; it is also favorable to the formation of an adequate micro clime to the germination and survival of the seedlings (Lahde, 1974).

Different materials with different sizes, shapes and colors had been used as physical protectors by many researches (Barnett and Baker, 1991; Serpa and Mattei, 1999; Mattei et al., 2001; Klein, 2005; Klein et al., 2005; Ferreira et al., 2007). According to Carneiro (1995), those protectors must be light, non-toxic, hygroscopic and must recover all soil surface. It is observed in the literature that some benefits of the use of physical protectors when used in the sowing points, contributes to the higher emergence and survival rates in the first months for plants of Pinus elliotti (Mattei, 1998; Mattei et al., 2001), Pinus taeda (D'Arco, 1999) and in plants of Enterolobium contortisiliqum and P. dubium (Malavasi et al., 2010). However, there are no reports of physical protectors associated with colored polymers. With all these aspects mentioned above, this study aim to evaluate the influence of physical protectors of different filters in the initial development of $P$. dubium (Spreng.) Taub. seedlings.

\section{MATERIALS AND METHODS}

The experiment was performed between April to December, 2007, in open area of the Botanic department ( $48^{\circ} 26^{\prime} \mathrm{W}, 2^{\circ} 52^{\prime} \mathrm{S}$ ), Institute of Biosciences, State University "Julio de Mesquita Filho" (UNESP), Botucatu - Sao Paulo State, Brazil. The fruits were collected from matrix trees located in the city of Botucatu - SP. After collection, the seeds were removed from the fruits and clean with the help of a sieve, and after that, they were mixed and selected, thereafter, disposing the damaged ones.

The determination of the physical characteristics of the seeds, was determined with the percentage of germination, level of seed moisture, drying them at $103^{\circ} \mathrm{C}$ for $24 \mathrm{~h}$, weight of one thousand seeds and number of seeds per kilogram. The calculations were performed according to the recommendation of the Rules for Seeds Analysis (Brasil, 2009). The seeds of canafistula were submitted to manual mechanical scarification, by the use of a sandpaper number P 80 (Piroli et al., 2005), for the overcome of dormancy (Viecelli et al., 2011). After that, the seeds were submerse in water to room temperature for $8 \mathrm{~h}$ and seeds which showed numbness and signs of the imbibition were selected for the sowing. These seeds, were taken to the experimental area for the sowing in vases of 12 liters containing a Rhodic Hapludox, characteristic from the region, was corrected and fertilizer 60 days before the sowing.

The test of germination was performed with five subsamples of 20 seeds, in a acclimatized room, with light exposure from fluorescent lamps $(20 \mathrm{~W})$, internally fixed, with temperature between 20 to $30^{\circ} \mathrm{C}$ and photoperiod of $8 \mathrm{~h}$ of light. The experimental design was completely randomized, with four treatments and ten replications. The physical protector used, was constituted from P.E.T. bottles (polyethylene terephthalate), with a volume of 2,500 ml without bottom and with cover. Different length waves were obtained engaging the P.E.T. bottles with two layers of cellophane paper with different colors (transparent, blue and red). 
Table 1. Evaluation of the physical characteristics and initial viability of Peltophorum dubium (Spreng.) Taub. seeds, performed after 8 months of storage.

\begin{tabular}{cc}
\hline Weight of one thousand seeds $(\mathbf{g})$ & Number of seeds per $\mathbf{k g}$ \\
\hline 34.93 & 28,629 \\
& \\
Seed moisture content & Germination \\
7.23 & $90 \%$ \\
\hline
\end{tabular}

Table 2. Speed Index of emergence Peltophorum dubium (Spreng.) Taub, subjected to treatment with the presence or absence of colored protectors at 8, 11, 16, 24 and 48 days after sowing (DAS).

\begin{tabular}{lccccc}
\hline \multirow{2}{*}{ Treatment } & \multicolumn{5}{c}{ Days after sowing (DAS) } \\
\cline { 2 - 6 } & $\mathbf{8}$ & $\mathbf{1 1}$ & $\mathbf{1 6}$ & $\mathbf{2 4}$ & $\mathbf{4 8}$ \\
\hline Absence of physical protector & $0.0^{\mathrm{C}}$ & $20.0^{\mathrm{C}}$ & $55.0^{\mathrm{C}}$ & $65.0^{\mathrm{C}}$ & $65.0^{\mathrm{C}}$ \\
Transparent physical protector & $5.0^{\mathrm{B}}$ & $37.5^{\mathrm{B}}$ & $80.0^{\mathrm{A}}$ & $80.0^{\mathrm{A}}$ & $80.0^{\mathrm{A}}$ \\
Blue physical protector & $7.5^{\mathrm{AB}}$ & $62.5^{\mathrm{A}}$ & $82.5^{\mathrm{A}}$ & $82.5^{\mathrm{A}}$ & $82.5^{\mathrm{A}}$ \\
Red physical protector & $10.0^{\mathrm{A}}$ & $60.0^{\mathrm{A}}$ & $72.5^{\mathrm{B}}$ & $75.0^{\mathrm{B}}$ & $75.0^{\mathrm{B}}$ \\
CV (\%) & & & 6.23 & & \\
F & & & $14.82^{*}$ & & \\
LSD & & 4.81 & & \\
\hline
\end{tabular}

Means followed by same letter in column do not differ significantly by Tukey test at $5 \%$ probability. CV, Coefficient of variation; LSD, least significant difference.

This way, the following treatments were obtained: T1: no physical protector; T2: transparent physical protector; T3: transparent physical protector + blue cellophane and T4: transparent physical protector + red cellophane. Daily, the following evaluations was performed: emergence speed index (ESI): The seedlings emergence evaluations were performed daily for 48 days after sowing, seedlings which present cotyledonary leaves were completely expanded and emerged; percentage of survival and seedlings emergence: This was initiated after the first emerged plant and it was concluded in 48 days after sowing, when the protectors were removed to avoid the effect of the environment pollution; height of plants: This was determined measuring the distance from the root collar to the terminal bud of the plant; diameter of the root collar: Measure performed with a digital caliper and expressed in millimeters; and leaf area: This was defined as the surface of the blade leaf measure performed with the use of an instrument called area meter, model LI-3100 $\left(\mathrm{cm}^{2}\right)$.

The obtained results were tested with the suppositions of normality and homoscedasticity for parametric tests, by ShapiroWilk and Levene. After that, the analysis of variance (ANOVA) was performed and regression analysis was used also with the program SIGMA PLOT, which described the interactions between the evaluated characteristics. The treatments means were compared by the Tukey test at $5 \%$ of probability. For the evaluations of emergence percentage and survival the means were transformed in arccosine of the square root of $x / 100$.

\section{RESULTS AND DISCUSSION}

The canafistula seedlings presented a percentage of moisture around $7 \%$. In relation to the number of seeds per kilogram and the weight of one thousand seeds
(Table 1), the obtained results reveals that the seeds of canafistula presented a common behavior just like the most pioneer species, as described by Wanli et al. (2001). In general, the canafistula present itself as a great option for reforestation projects, due to its great viability even with low content of water, high quantity of seeds per kilogram and the presence of a dormancy mechanism.

The first emergence of canafistula seedlings in the presence of the physical protector, independent of the color, initiate at 8 days after sowing and the maximum of seedlings emergence was observed 16 days after sowing (Table 2). In the other hand, the first emergences occur in the absence of the physical protector detected, only at 11 days after sowing, being the maximum of seedlings emergence observed only at 20 days after sowing. This increase in the emergence speed is probably due to the function of high taxes of temperature and moisture inside physical protectors (Table 3 ).

This results, confirm what was observed by Klein et al. (2005), the temperature inside the physical protectors, P.E.T. bottles in three different heights. The same authors observed the increase of nearly $2^{\circ} \mathrm{C}$ in the interior of the physical protectors in relation to the environmental temperature, no matter how high the protector height.

The use of protectors was also responsible for the increase of the soil moisture and the increase of the the germination and survival study with different forest 
Table 3. Temperature and air relative moisture in the seeding points from Peltophorum dubium (Spreng.) Taub. 48 days after sowing.

\begin{tabular}{lcc}
\hline Treatment & Temperature & Air moisture \\
\hline Absence of physical protector & $21.00^{\mathrm{A}}$ & $47.90^{\mathrm{B}}$ \\
Transparent physical protector & $22.20^{\mathrm{A}}$ & $68.90^{\mathrm{A}}$ \\
Blue physical protector & $21.70^{\mathrm{A}}$ & $69.20^{\mathrm{A}}$ \\
Red physical protector & $22.50^{\mathrm{A}}$ & $69.80^{\mathrm{A}}$ \\
CV (\%) & 5.31 & 12.50 \\
F & $1.02^{\mathrm{ns}}$ & $10.93^{\star}$ \\
LSD & 1.67 & 11.37 \\
\hline
\end{tabular}

Means followed by same letter in column do not differ significantly by Tukey test at $5 \%$ probability. CV, Coefficient of variation; LSD, least significant difference.

species in the no tillage system (Santos-Junior et al., 2004). The same type of physical protector was also responsible for the increase in the internal temperature of this environment independently of the year station evaluated (Klein, 2005).

In relation to the emergence speed index (ESI) inside each treatment, those without cover and also with colors presented quadratic behavior (Table 2). In this way, the ESI of the seedlings presented higher values of emergence between 20 and 30 days after sowing. In the other side, for the decomposition of the response in each evaluation (Table 2) significant difference was verified between the treatments in all perform evaluations, where higher ESI was also detected in the seedlings which were inside the physical protectors, independently of the color of the filter.

The emergence percentage of canafistula seedlings presented an increase in all treatments between 16 and 24 days after emergence. But, the largest significant difference was verify between 11 and 16 days after emergence, where all the treatments with physical protector, independently of the filter, originate superior values when compared to the one observed in the absence of the physical protector, being equal at 115 , 107 and 100\% for the blue protector (BLUE), transparent protector (TRANSP), and red protector (RED), respectively. This way, the higher seedlings emergence may have occur because of the increase of the temperature and phytochrome influence, probably because, the physical protectors may have allowed the canafistula seeds a higher period of time in the optimal temperature for germination, that would explain the maximal germination percentage in a very short time (Silva et al., 2004).

In a study with Cedrela fissilis, Mattei. (1995) reports that the used physical protector, a plastic cup of $250 \mathrm{ml}$, without bottom and with the largest circumference of the circle to the face down, promoted an increase in the tax of germination. Mattei and Rosenthal (2002), notice that protectors as plastic cups and paper cups, without bottom, contributed in the initial emergence and in the establishment of the canafistula seedlings evaluated at 18 months after sowing. Conflicting results were observed by Ferreira et al. (2007), in a study with Senna multijuga, observed significant effect for the physical protector, which correspond to transparent plastic pots of $500 \mathrm{ml}$ without bottom, putted above the sowing points. The mean values of canafistula seedlings survival emerged 48 days after sowing, independently of the treatment, were $85 \%$ superiors (Table 4 ), which means that the survival of the emerged seedlings was influenced by the physical protectors independently of the color of the filter. The weakness of seedlings in function to the soil compression resulted because of the less moisture observed as the principal factor of the cause of seedlings death.

Serpa and Mattei (1999), observed a larger percentage of survival in plants of Pinus taeda, used for timber and cellulose originated in the interior the physical protectors. Besides, Santos-Junior et al. (2004) observed an increment in the survival percentage of Tabebuia serratifolia, used for landscape and reforestation, while physical protector used for transparent plastic cups of $500 \mathrm{ml}$ without bottom and buried $2 \mathrm{~cm}$ under the hole, was in relation to the absence of physical protector. The increase, promoted by the physical protector in the survival of seedlings can be directly related to the ecological group which the vegetal species is classified (Perez et al., 2001). In this way, the protector initiates great benefits to slow development species (Ferreira et al., 2007).

The mean values obtained at 48 DAS of plant height, observe that the blue and red physical protectors provided significant growth of stem in comparison to the other treatments (Table 5). The transparent physical protector promoted the third higher increment of this variable, without significant difference in the height provided by the absence of the physical protector. The use of the physical protectors associated with color filters in the points of sowing can interfere in the quality of light in seeds and seedlings, stimulating or causing inhibition in different physiological processes. According to 
Table 4. Mean values of seedling survival Peltophorum dubium (Spreng.) Taub., submitted to treatment with the presence or absence of colorful protectors 48 days after sowing.

\begin{tabular}{lc}
\hline Treatment & Survival (\%) \\
\hline Absence of physical protector & $878^{\mathrm{B}}$ \\
Transparent physical protector & $932^{\mathrm{A}}$ \\
Blue physical protector & $966^{\mathrm{A}}$ \\
Red physical protector & $954^{\mathrm{A}}$ \\
CV (\%) & 732 \\
F & $706^{\star}$ \\
LSD & 452 \\
\hline
\end{tabular}

Means followed by same letter in column do not differ significantly by Tukey test ta t $5 \%$ probability. $\mathrm{CV}$, Coefficient of variation; LSD, least significant difference.

Table 5. Mean values of height, leaf area and root collar diameter of seedlings were Peltophorum dubium (Spreng.) Taub., submitted to treatment with the presence or absence of colorful protectors 48 days after sowing.

\begin{tabular}{lccc}
\hline Treatment & Height $\mathbf{( c m})$ & Leaf area $\left(\mathbf{d m}^{2}\right)$ & Root collar diameter $(\mathbf{m m})$ \\
\hline Absence of physical protector & $5.3^{\mathrm{B}}$ & $9.9^{\mathrm{B}}$ & $1.4^{\mathrm{A}}$ \\
Transparent physical protector & $5.6^{\mathrm{B}}$ & $11.0^{\mathrm{B}}$ & $1.5^{\mathrm{A}}$ \\
Blue physical protector & $9.3^{\mathrm{A}}$ & $15.3^{\mathrm{B}}$ & $1.8^{\mathrm{A}}$ \\
Red physical protector & $7.6^{\mathrm{A}}$ & $21.3^{\mathrm{A}}$ & $1.1^{\mathrm{A}}$ \\
CV (\%) & 9.9 & 21.29 & 18.29 \\
F & $1.17^{*}$ & $3.91^{*}$ & $0.45^{\mathrm{ns}}$ \\
LSD & 1.86 & 8.63 & 0.84 \\
\hline
\end{tabular}

Means followed by same letter in column do not differ significantly by Tukey test ta t $5 \%$ probability. CV, Coefficient of variation; LSD, least significant difference.

Almeida and Mundstock (2001), many signaling when presented in the different plant tissues can be responsible for acting in the vegetal growth in function of quality and quantity of the received light. For Taiz and Zeiger (2004), the increment in the stem stretching reveals the response to light intensity reduction on the seedlings, which indicate the involvement of the phytochrome in this perception.

The same behavior was found in Cattleya loddigessi, where Braga et al. (2007) verified that the shoot system and the root system grown were promoted by the red mesh. The influence of the blue, black and red mesh in the plant height was also verified in Aralia sp., Monstera deliciosa, Aspidistra elatior and Asparagus sp. (Shahak et al., 2002). The no tillage system in the presence of the red physical protector provided higher mean values for the leaf blade area when compared to the other treatments (Table 5). The plants which was grown in the interior of the red physical protector presented mean values for leaf area around $21.30 \mathrm{dm}^{2}$, and the other treatments without physical protector, transparent physical protector and blue physical protector presented
$9.90,11.00$ and $15.30 \mathrm{dm}^{2}$, respectively. Those values suggested a positive correlation between the reduction in the light quantity received, photosynthetically active radiation (PAR) and the values of shoot system area. In this context, Larcher (2004), reports about the heliophytic plants during the evolution and how this species develop efficient strategies in order to maximize the electron transportation to the chloroplast, even in low radiation intensities. However, presenting high percentages of leaf area can be one important alternative in reforestation projects (Coelho Filho et al., 2005), mainly in relation to the initial development of seedlings.

In the present study, the mean value of the root collar in canafistula seedlings was not influenced by the different treatments after 48 DAS (Table 5). It is important to affirm that those treatments did not prejudice in the initial development of canafistula in the evaluated period. When the obtained mean values with the use of red physical protector was analyzed it was observed that they were 25,31 and $40 \%$ respectively, lower to the ones obtained in the absence of physical protector, transparent physical protector and blue physical protector, 
respectively.

Guariz et al. (2006), evaluated the diameter and height growth of Posoqueira acutifólia seedlings in different solar radiation levels and it was observed that as the shading level was increased, the root collar diameter decreased. The same result was obtained by Aguiar et al. (2005), analyzing the influence of different levels of shading in the initial development of Caesalpinia echinata seedlings which presented higher mean values in the root collar diameter in relation to the plants maintained in full sunlight.

\section{Conclusion}

All types of physical protectors increased the mean values of EVI and survival. In the conditions of this study, emergence speed and the initial development of $P$. dubium (Spreng.) seedlings grown in the interior of physical protectors, independently on the filters, presented positive result. The reductions on the light intensity interfere positively in the initial growth of plants.

\section{Conflict of Interest}

The authors have not declared any conflict of interest.

\section{REFERENCES}

Aguiar FFA, Kanashiro S, Tavares AR, Pinto MM, Stancato GC, Aguiar J, Nascimento TDR (2005). Germinação de sementes e formação de mudas de Caesalpinia echinata lam. (pau-brasil): efeito de $\begin{array}{lll}\text { sombreamento. Rev. 29(6):871-875. } & \end{array}$ http://dx.doi.org/10.1590/S0100-67622005000600005

Almeida ML, Mundstock CM (2001). O afilhamento da aveia afetado pela qualidade de luz em plantas sob competição. Ciência Rural 31(3):393-400. http://dx.doi.org/10.1590/S0103-84782001000300005

Barnett JP, Baker JB (1991). Regeneration Methods. In: Duryea ML, Dougherty PM (Ed) Forest regeneration manual. London: Kluwer Academic Publishers 3:35-50.

Braga FT, Oliveira C, Pasqual M, Castro EM, Almeida GW, Dignart SL, Costa LCB (2007). Crescimento de Cattleya loddigesii "alba x alba" in vitro mantida sob telas coloridas. In: Congresso De Ecologia Do Brasil, 2007, Caxambu-MG. Anais... Caxambu VIII CEB, pp. 1-2.

Brasil. Ministério da Agricultura Pecuária e Abastecimento (2009). Regras para análise de sementes. Brasília: SNDA/DNDV/CLAV. P. 399.

Carneiro JGA (1995). Produção e controle de qualidade de mudas florestais. Curitiba: Universidade Federal do Paraná/FUPEP, UENF 451p.

Coelho Filho MA, Angelocci LR, Vasconcelos MRB, Coelho EF (2005). Estimativa da área foliar de plantas de lima ácida 'tahiti' usando métodos não-destrutivos. Revista Brasileira de Fruticultura 27(1):163-167.http://dx.doi.org/10.1590/S0100-29452005000100043

D'Arco E (1999). Estabelecimento e desenvolvimento inicial de Pinus taeda L. em semeadura direta, sob efeito do preparo localizado do solo, protetor físico e cobertura das sementes. Pelotas, 1999. 60p. Dissertação (Mestrado em Agronomia) - Curso de Agronomia, Universidade Federal de Pelotas.

Derr HJ, Mann Jr. WF (1971). Direct seeding pines in the south. Washington, DC: USDA. Forest service. (Agricultural Handbook 391:68.

Donadio NMM, Demattê MESP (2000). Morfologia de frutos, sementes, e plântulas de canafístula (Peltophorum dubium (Spreng.) Taub.) e jacarandá-da-Bahia (Dalbergia nigra (Vell.) Fr. All. ex Benth.) Fabaceae. Revista Brasileira de Sementes 22(1):64-73.

Ferreira RA (2002). Estudo da semeadura direta visando à implantação de matas ciliares. Tese (doutorado em agronomia). Universidade Federal de Lavras/MG. 138p.

Ferreira RA, Davide AC, Bearzoti E, Motta MS (2007). Semeadura direta com espécies arbóreas para recuperação de ecossistemas florestais. Revista Cerne 13(3):271-279.

Guariz HR, Faria PAS, Pezzopane JEM, Reis EF (2006). Avaliação do crescimento em diâmetro e altura de mudas de canela (Posoqueira acutifolia Mart.) sob diferentes níveis de radiação solar. In: X Encontro Latino Americano de iniciação científica e VI Encontro Latino Americano de pós-graduação, 2006, São José dos Campos. Anais... São José dos Campos: UVP, pp. 2828-2830.

Klein J (2005). Utilização de protetores físicos na semeadura direta de timburi e canafístula na revegetação de matas ciliares.. Dissertação (Mestrado em agronomia) - Universidade Estadual do Oeste do Paraná, Marechal Cândido Rondon / PR. P. 95.

Klein J, Kestring D, Schwantes D, Repke RA, Mezzalira EJ, Piva AL, Arrua MAM, Javorski CR, Rodrigues JD, Guimaraes VF (2012). Influence of light quality on germination and initial growth of canephori seedlings Peltophorum dubium (Sprenge) Taub. J. Food Agric. Environ. 10:947-951.

Klein J, Malavasi UC, Malavasi MM, Aleixo V (2005). Variação da temperatura do ar em protetores físicos utilizados na semeadura direta. In: III Jornada Científica da Unioeste, 2005, Marechal Cândido Rondon/PR. III Jornada Científica da Unioeste pp. 152-158.

Lahde E (1974). The effect of seed-spot shelters and cold stratification on pine (Pinus sylvestris L.). Folia For. 196:1-16.

Larcher W (2004). Ecofisiologia vegetal. São Carlos: RiMa. P. 337.

Lorenzi H (2000). Árvores brasileiras. Nova Odessa: Plantarum. P. 352.

Malavasi UC, Klein J, Malavasi MM (2010). Efeito de um protetor físico na semeadura direta de duas espécies florestais em área de domínio ciliar. Rev. Árvore 34(5):781-787. http://dx.doi.org/10.1590/S010067622010000500003

Mattei VL (1995). Preparo de solo e uso de protetor físico, na implantação de Cedrela fissilis V. e Pinus taeda L., por semeadura direta. Rev. Bras. Agrociência 1(3):127-132.

Mattei VL (1998). Materiais de cobertura em semeadura de Pinus elliotti Engelm e Pinus taeda L., diretamente no campo. Rev. Bras. Agrociência (4(1):64-68.

Mattei VL (1999). Semeadura direta de Peltophorum dubium (Spreng.) Taub. No enriquecimento de capoeiras. Rev. Árvore 2:85-96.

Mattei VL, Romano CA, Teixeira MCC (2001). Protetores físicos para semeadura direta de Pinus elliottii Engelm. Ciência Rural 31(5):775 780.

Mattei VL, Rosenthal MD (2002). Semeadura direta de canafistula [Peltophorum dubium (Spreng.) Taub.] no enriquecimento de capoeiras. Rev. Árvore 26(6):649-654. http://dx.doi.org/10.1590/S0100-67622002000600001

Meneghello GE, Mattei VL (2004). Semeadura direta de timbaúva (Enterolobium contortisiliquum), canafístula (Peltophorum dubium) e cedro (Cedrela fissilis) em campos abandonados. Ciência Florestal 14(2):21-27.

Neves CSVJ, Medina CC, Azevedo MCB, Higa AR, Simon A (2005). Efeitos de substratos e recipientes utilizados na produção das mudas sobre a arquitetura do sistema radicular de árvores de acácia-negra. Rev. Árvore 29(6):897-905. http://dx.doi.org/10.1590/S010067622005000600008

Oliveira LM, Davide AC, Carvalho MLM (2003). Avaliação de métodos para quebra da dormência e para a desinfestação de sementes de canafístula (Peltophorum dubium (Sprengel) Taubert). Rev. Árvore 27:597-603. http://dx.doi.org/10.1590/S0100-67622003000500001

Paulino AF, Medina C, Azevedo MCB, Silveira KRP, Trevisan AA Murata IM (2004). Escarificação de um Latossolo Vermelho na póscolheita de soqueira de cana-de-açúcar. R. Bras. Ci. Solo 28(5):911917. http://dx.doi.org/10.1590/S0100-06832004000500013

Perez SCJGA, Fanti SC, Casali CA (2001). Salt stress and salt temperature interaction on the germination of Peltophorum dubium seeds. J. Trop. For. Sci. 13(1):44-61.

Piroli EL, Custódi CC, Rocha MRV, Udenal JL (2005). Germinação de 
sementes de canafístula Peltophorum dubium (Spreng.) taub. tratadas para superação da dormência. Colloquium Agrariae 1(1):1318.

Salerno AR, Schallenberger TCH, Stuker H (1996). Quebra da dormência em sementes de Canafístula. Agropecuária Catarinense 9(1):9-11.

Santos-Júnior NA, Botelho AS, Davide AC (2004). Estudo da germinação e sobrevivência de espécies arbóreas em sistema de semeadura direta, visando à recomposição de mata ciliar. Rev. Cerne 10(1):103-117.

Serpa MR, Mattei VL (1999). Avaliação de diferentes materiais de cobertura e de um protetor físico, no estabelecimento de plantas de Pinus taeda L., por semeadura direta no campo. Ciência Florestal 9(2):93-101.

Shahak Y, Ratner K, Ovadia R, Giller YE (2002). Growing Aralia and Monstera under colored shade nets. Olam Poreah July Issure 13:6062.

Silva EC, Nogueira RJ, MC, Neto ADA, Brito JZ, Cabral EL (2004). Aspectos ecofisiológicos de dez espécies em uma área de caatinga no município de Cabaceiras, Paraíba, Brasil. Iheringia 59(2):201-205.

Soares PG, Rodrigues RR (2008). Semeadura direta de leguminosas florestais: efeito da inoculação com rizóbio na emergência de mudas e crescimento inicial no campo. Sci. For. 78:115-121.

Souza VC, Andrade LA, Bruno RLA, Cunha AO, Souza AP (2005). Produção de mudas de ipê-amarelo (Tabebuia serratifolia (Vahl.) Nich.) em diferentes substratos e tamanho de recipientes. Agropecuária Técnica 26(2):98-108.

Taiz L, Zeiger E (2004). Fisiologia Vegetal. Sinauer Associates Inc. Sunderland, USA. P. 764.
Teles MM, Alves AA, Oliveira JCG, Bezerra AME (2000). Métodos para quebra da dormência em sementes de leucena (Leucaena leucocephala (Lam.) de Wit. R. Bras. Zootec. 29:387-391. http://dx.doi.org/10.1590/S1516-35982000000200010

Viecelli CA, Fiorese EJ, Rampim L, Guimaraes VF (2011). Quebra da dormência de sementes de canafístula (Peltophorum dubium (Spreng) Taubert) e íris (Iris germanica). Revista de Biologia e Saúde da UNISEP 4(2):28-35.

Wanli Z, Leihong L, Perez SCJGA (2001). Pré-condicionamento e seus efeitos em sementes de canafístula (Peltophorum dubium (Spreng.) Taub.). Rev. Bras. Sementes 23:146-153. 